\title{
SOIL ORGANISMS IN ORGANIC AND CONVENTIONAL CROPPING SYSTEMS
}

\author{
Wagner Bettiol',2*; Raquel Ghini'1,2; José Abrahão Haddad Galvão'; Marcos Antônio Vieira \\ Ligo $^{1}$; Jeferson Luiz de Carvalho Mineiro ${ }^{1}$ \\ ${ }^{1}$ Embrapa Meio Ambiente, C.P. 69 - CEP: 13820-000 - Jaguariúna, SP. \\ ${ }^{2} \mathrm{CNPq}$ Fellow. \\ *Corresponding author <bettiol@cnpma.embrapa.br>
}

ABSTRACT: Despite the recent interest in organic agriculture, little research has been carried out in this area. Thus, the objective of this study was to compare, in a dystrophic Ultisol, the effects of organic and conventional agricultures on soil organism populations, for the tomato (Lycopersicum esculentum) and corn (Zea mays) crops. In general, it was found that fungus, bacterium and actinomycet populations counted by the number of colonies in the media, were similar for the two cropping systems. $\mathrm{CO}_{2}$ evolution during the cropping season was higher, up to the double for the organic agriculture system as compared to the conventional. The number of earthworms was about ten times higher in the organic system. There was no difference in the decomposition rate of organic matter of the two systems. In general, the number of microartropods was always higher in the organic plots in relation to the conventional ones, reflectining on the Shannon index diversity. The higher insect population belonged to the Collembola order, and in the case of mites, to the superfamily Oribatuloidea. Individuals of the groups Aranae, Chilopoda, Dyplopoda, Pauropoda, Protura and Symphyla were occasionally collected in similar number in both cropping systems.

Key words: soil microorganisms, organic agriculture, microartropods, cropping systems, environmental impacts

\section{ORGANISMOS DO SOLO EM SISTEMAS DE CULTIVO ORGÂNICO E CONVENCIONAL}

\begin{abstract}
RESUMO: Apesar do crescente interesse pela agricultura orgânica, são poucas as informações de pesquisa disponíveis sobre o assunto. Assim, num Argissolo Vermelho-Amarelo distrófico foram comparados os efeitos de sistemas de cultivo orgânico e convencional, para as culturas do tomate (Lycopersicum esculentum) e do milho (Zea mays), sobre a comunidade de organismos do solo e suas atividades. As populações de fungos, bactérias e actinomicetos, determinadas pela contagem de colônias em meio de cultura, foram semelhantes para os dois sistemas de produção. A atividade microbiana, avaliada pela evolução de $\mathrm{CO}_{2}$, manteve-se superior no sistema orgânico, sendo que em determinadas avaliações foi o dobro da evolução verificada no sistema convencional. O número de espécimes de minhoca foi praticamente dez vezes maior no sistema orgânico. Não foi observada diferença na taxa de decomposição de matéria orgânica entre os dois sistemas. De modo geral, o número de indivíduos de microartrópodos foi superior no sistema orgânico do que no sistema convencional, refletindo no maior índice de diversidade de Shannon. As maiores populações de insetos foram as da ordem Collembola, enquanto para os ácaros a maior população foi a da superfamília Oribatuloidea. Indivíduos dos grupos Aranae, Chilopoda, Dyplopoda, Pauropoda, Protura e Symphyla foram ocasionalmente coletados e de forma similar entre os sistemas.

Palavras-chave: microbiota do solo, agricultura orgânica, microartrópodos, sistemas de cultivo, impacto ambiental
\end{abstract}

\section{INTRODUCTION}

Contamination of the water-soil-plant system with pesticides and fertilizers, in addition to breaking up the soil structure due to inadequate use of machinery and implements, is one of the main problems caused by intensive agriculture. The implementation of integrated cropping systems and the reduction of the external energy requirements have been suggested to minimize these problems. The organic cropping system is defined as a production system that is sustainable in time and space, by means of management and protection of the natural resources, without the use of chemicals that are aggressive to humans and to the environment, retaining fertility increases, soil life and biological diversity. Thus, the use of highly soluble fertilizers, pesticides and growth regulators must be excluded in this system (Paschoal, 1995). Not only does the system have to satisfy the need for reducing the environmental negative-impact problems caused by intensive agriculture, it must also be economically competitive. In comparing the organic and the conventional cropping systems, an important step is to establish which social, economic and ecological factors influence the production systems the most. Besides, a knowledge of those factors allows for a better understanding of how the production systems are structured and how they work.

With respect to the biological activity, in studies to compare the conventional, integrated and organic cropping systems, Bokhorst (1989) found that the number 
of worms in a soil planted with sugar beets was five times higher in the organic system than in other systems, and that the percentage of wheat and potato roots infected with arbuscular mycorrhizae was twice as high in the organic as compared to the conventional and integrated systems. Gliessman et al. (1990, 1996), working with similar objectives, compared conventional and organic strawberry cropping systems in areas where farmers became organic producers, and verified an increase in the number of plants infected with mycorrhizae. Swezey et al. (1994) found higher microbial biomass in the soil and in arbuscular mycorrhizae in the organic system than in the conventional, in an area being changed from conventional into an organic apple growing area. All these studies emphasize the biological elasticity in the organic systems as a fundamental characteristic, influencing the occurrence of pests and diseases.

With regard to soil organisms, Brussaard et al. $(1988,1990)$ verified that the total biomass of soil organisms was higher for the integrated than for the conventional cropping system, with figures averaging 907 $\mathrm{kg} \mathrm{C} \mathrm{ha-1}$ and $690 \mathrm{~kg} \mathrm{C} \mathrm{ha}^{-1}$, respectively. Of these biomasses, bacteria accounted for over $90 \%$, fungi represented approximately $5 \%$ and protozoa were less than $2 \%$ of the total biomass. El Titi \& Ipach (1989) studied the effect of a cropping system with low input rate index as well as the conventional system on the soil fauna components and observed there were smaller populations of nematodes pathogenic to plants, higher worm biomass, and larger populations of collembolans and Mesostigmata mites in the system with low input index. Collembola is a microarthropod related to the soil's capacity to suppress Rhizoctonia solani (Lartey et al., 1994). Rickerl et al. (1989) found that populations of this organism were $29 \%$ larger in soils under minimum tillage as compared to soils under conventional tillage. Ladd et al. (1994) verified that the C biomass of microbial populations was greater in soils under crop rotation than in soils under continuous monoculture; greater in soils where plant residues were incorporated or remained on the soil surface than where they were removed; and smaller in a nitrogen-fertilized soil than in non-fertilized ones. This information is important because these are characteristics that contribute to soil biological equilibrium, nutrient mineralization and suppressive capacity toward plant pathogens, among others, making the system less dependent on external input.

The objective of this work was to evaluate the influence of the organic and the conventional cropping systems, for tomato and corn, on the community of soil organisms.

\section{MATERIAL E METHODS}

The experiment was carried out in Jaguariúna, SP, Brasil, latitude $22^{\circ} 41^{\prime} \mathrm{S}$, longitude $47^{\circ} \mathrm{W}$ Gr., and an altitude of $570 \mathrm{~m}$, on a dystrophic Ultisol, with the following chemical properties of the 0-0.2 $\mathrm{m}$ topsoil layer, before liming: $\mathrm{pH}\left(\mathrm{CaCl}_{2}\right)$ 4.4; OM 0.6\%; $\mathrm{P}$ (resin) $1 \mu \mathrm{g}$ $\mathrm{cm}^{-3}$; K 0.5; Ca 7; Mg 7; H + Al 28; CEC 43 and S 15 $\mathrm{mmol} \mathrm{dm} \mathrm{dm}^{-3}$ of soil; and $\mathrm{V} 35 \%$. The studies were conducted from January 1993 to September 1995.

The experiment was set up as randomized blocks with six replicates, and plots measuring $25 \times 17 \mathrm{~m}$. Tomato planting pits were spaced $0.5 \mathrm{~m}$ apart with $1.20 \mathrm{~m}$ between rows. Each plot was split in two halves, the first $12.5 \times 17$ $\mathrm{m}$-half being planted with the variety Débora and the other planted with the variety Santa Clara. Therefore, each of the twelve rows contained 17 planting pits for each variety. The edging between plots was $10 \mathrm{~m}$ wide and was planted with sorghum. Two tomato plants were transplanted per pit. The tomato crop was conducted using the stake system, with one or two stems/plant. The number of stems was determined based on the successful establishment of the seedlings. Furrow irrigation and plant pruning were performed as often as necessary.

The entire area received $4.2 \mathrm{t} \mathrm{ha}^{-1}$ lime and $2 \mathrm{~kg}$ per meter, 110 and 12 days before planting, respectively. Fertilization in the organic system employed $2.5 \mathrm{~L}$ of organic compost $\left(\mathrm{pH}=6.4 ; \mathrm{C}=29.6 \% ; \mathrm{N}=1.6 \% ; \mathrm{P}_{2} \mathrm{O}_{5}=1.8\right.$; $\mathrm{K}_{2} \mathrm{O}=0.17 \%$ and $\mathrm{U}=25.3 \%$ ) plus $130 \mathrm{~g}$ of single superphosphate/pit; additionally, $2.5 \mathrm{~L}$ of organic compost, $60 \mathrm{~g}$ of single superphosphate, and $60 \mathrm{~g}$ of dolomitic lime/pit were applied as sidedressing; plants were sprayed twice a week with biofertilizer (Bettiol et al., 1997), at concentrations of 5 or $10 \%$. In the conventional system, fertilization consisted of $200 \mathrm{~g} \mathrm{4-14-8} \mathrm{(NPK)/pit}$ and, after planting, a sidedressing application of $30 \mathrm{~g} \mathrm{~N}$, $33 \mathrm{~g} \mathrm{~K}$ and $10.5 \mathrm{~g} \mathrm{P} / \mathrm{pit}$; 52 days after planting and beyond, plants were sprayed once a week with foliar fertilizer [5-8-0,5 (NCaB)] at a rate of $3 \mathrm{~mL} \mathrm{~L}^{-1}$.

In the conventional system, $0.15 \mathrm{~g} / \mathrm{pit}$ of active ingredient of the insecticide carbofuram were applied before planting. According to the procedures utilized by conventional local growers, a blend of insecticides, fungicides and miticides was sprayed twice a week, after planting. Active ingredients of fungicides sprayed during the crop cycle were metalaxyl, mancozeb, chlorothalonil, copper oxychloride, kasugamycine, cuprous oxide, methyl thyophanate, iprodione, benomyl, cymoxamil, maneb and monohydrate zinc sulphate, at the rates recommended by the manufacturers. Insecticides used were deltamethrin, permethrin, methomyl, methamidophos, acephate, avermectin and cartap, also at the recommended rates.

Extracts of black pepper, Eucalyptus, garlic and fern; Bordeaux mixture, and biofertilizer were applied twice a week (Bettiol et al., 1997; Abreu Junior, 1998) to control diseases and pests in the organic system. These applications were performed according to the program adopted by organic producers in the region.

Weed control was carried out by mechanical weeding and with the herbicide glyphosate (directed spray) on post-planting in the conventional system, and with mechanical weeding in the organic system. 
After harvesting the tomato the area was planted with 'BR 201' corn; sowing occurred 178 days after planting the tomatoes. The organic system plots received an application of $4 \mathrm{~m}^{3}$ of organic compost and single superphosphate at the rate of $20 \mathrm{~g}$ per meter; in addition, the biofertilizer was sprayed at $10 \%$ as sidedressing. In the conventional system fertilization consisted of $500 \mathrm{~kg}$ $\mathrm{ha}^{-1}$ of the 4-14-8 NPK rate applied pre-planting and $15 \mathrm{~g}$ $\mathrm{m}^{-1}$ urea as sidedressing. Weed control used the herbicide paraquat (directed spray) in the conventional system, and mechanical weeding was used in the organic.

After harvesting the corn, 'Débora' tomatoes were again cultivated, as previously described. Transplantation was made 401 days after the initial tomato planting.

\section{Soil Microorganisms}

A sample composed of 20 sub-samples of soil taken at the planting row from the 0-7 cm-depth layer was obtained for each plot. Samples were placed in plastic bags and immediately transported to the laboratory. Assessments were performed within 24 hours after collecting the samples.

Populations of fungi, bacteria and actinomycetes: The populations of fungi, bacteria and actinomycetes were quantified through the serial-dilution method, followed by plating in culture medium. Martin's culture medium (Tuite, 1969) added of $100 \mathrm{mg} \mathrm{mL}^{-1}$ streptomycine was used for fungi; for bacteria, the agar nutrient medium added of nistatin (42 $\left.\mathrm{mg} \mathrm{L}^{-1}\right)$ was used; for the actinomycetes, the alkalized agar-water medium was utilized. Aliquots (0.1 $\mathrm{mL}$ ) from three dilutions, for each soil sample, were transferred to the culture media in three replications. Assessments were performed by counting the number of colonies per Petri dish and expressed as colony-forming units/g of dry soil (CFU g ${ }^{-1}$ dry soil).

Total respiratory activity: Total microbial respiration was evaluated according the method described by Grisi (1978). Soil samples (200 g) were incubated for 10,20 , and 30 days within tightly sealed containers holding $10 \mathrm{~mL}$ of a $0.5 \mathrm{~mol} \mathrm{~L}^{-1}(10 \mathrm{~mL}) \mathrm{KOH}$ solution. At 10-day intervals, the solution was substituted and titrated with $0.1 \mathrm{~mol} \mathrm{~L}^{-1}$ of $\mathrm{HCl}$. Incubation was conducted in the dark, at $25^{\circ} \mathrm{C}$. This parameter was expressed as $\mathrm{g} \mathrm{CO}_{2}\left(\mathrm{~g}\right.$ dry soil $\left.^{-1}\right)\left(\mathrm{day}^{-1}\right)$. Since the more substantial changes happened in the first days, only readings up to the tenth day were used to determine mean values. For the statistical analysis, data were transformed into square root $(x+0.5)$ and subjected to analysis of variance and Duncan's mean comparison test.

Soil microarthropods: Collecting was made with a Uhland-type, stainless steel auger $5 \mathrm{~cm}$ in diameter and 10 $\mathrm{cm}$ in height, totaling four samples per plot. Samples were placed in plastic bags and taken to the laboratory. Collecting was between 8:00 and 10:30 h, 82 days before and 325 days after the first tomato seeding, for a total of 16 evaluations. Extraction was according to Tullgren's modified method, which uses heat and desiccation to force the animals to leave the soil. Samples remained in the extractor for 72 hours. An alcohol:glycerin (1:1) aqueous solution was used for specimen preservation. After extraction, the animals were counted and separated into groups with the use of a stereoscopic microscope. Mites and other smaller animals were fixed on permanent slides for identification. Data were expressed as number of individuals per $785 \mathrm{~cm}^{3}$ soil. Shannon's diversity index (Shannon \& Weaver, 1949) was calculated for a better understanding of the variations in the soil microarthropod populations.

Organic matter decomposition rate estimate: The decomposition rate was estimated via loss of organic content from leaf litter confined in nylon bags, $20 \times 20$ $\mathrm{cm}$, with a $1 \mathrm{~mm}$ mesh, where $10 \mathrm{~g}$ of elephant grass dried at $60^{\circ} \mathrm{C}$ for three days. The field-collected samples, were collected every 20 days and transported to the laboratory, dried at $105^{\circ} \mathrm{C}$ for 24 hours and ashed at $600^{\circ} \mathrm{C}$ for 4 hours. The loss of organic matter estimate was calculated using the equation described by Santos \& Whitford (1981), which corrects for the adhesion of soil particles to the organic matter.

Evaluation of earthworms in the soil: The first evaluation was carried out 81 days before the first planting, i.e., before plowing and liming. A hand excavator was used to collect samples; two samples were collected from each plot, up to a depth of $20 \mathrm{~cm}$, with $20 \mathrm{~cm}$ diameter. Shortly after planting the tomatoes, and 90 days later, samples were taken at about $40 \mathrm{~cm}$ depth, with a diameter of $10 \mathrm{~cm}$. Three samples were collected from the compost: one from the pile surface; another at a layer up to $35 \mathrm{~cm}$, and the third at a depth of $90 \mathrm{~cm}$. The worm populations were determined 370,407 , and 471 days after the first tomato planting.

\section{RESULTS AND DISCUSSION}

The populations of fungi, bacteria and actinomycetes were similar for the two cropping systems over the entire period of study, with populations of fungi varying from $10^{4}$ to $10^{5}$, whereas populations of bacteria and actinomycetes varied from $10^{5}$ to $10^{7} \mathrm{CFU} \mathrm{g} \mathrm{g}^{-1}$ dry soil (Figure 1). Similar results were obtained by Castro et al. (1993), when several types of soybean management were compared, and by Cattelan \& Vidor (1990) on soils cultivated with different crop rotation systems. Grigorova \& Norris (1990) justified not adopting this method for evaluating soil microorganisms, because only a small fraction of microbial biomass could be cultivated on a selective medium. However, Cattelan \& Vidor (1990) demonstrated the effectiveness of the method in studies with different cropping systems. In spite of a similar behavior in regard to microbial populations, starting 145 days after planting the tomatoes, the bacteria populations (Figure 1 C) were higher in the organic system as compared to the conventional. This could be due to soil plant cover, like Cattelan \& Vidor (1990) who found a smaller bacterial population on naked as compared to cultivated soil. 
Soil total respiratory activity continued higher in the organic system during the crop cycles, showing in some evaluations twice as much as the evolution observed in the conventional system (Figure 2). Differences were found during the intermediate period, that is, between 142 and 400 days after planting. There were no statistical differences between treatments at the initial periods or at the end. The higher respiratory rate in the organic system could be due to the addition of an exogenous source of organic matter to the soil and the consequent stimulation of heterotrophic microorganisms (Lambais, 1997).

Observed organic matter decomposition rates ranged from 15 to $45 \%$ of organic carbon loss in a 20 -day period. Rodrigues et al. (1997) observed, in corn cultivated during the summer, values reaching $70 \%$ of carbon loss in a period of 30 days. There was no difference among results from the organic and the conventional systems (Figure 3). However, regardless of the system, there was an influence of time on the organic matter decomposition rate was, although no interaction between time and the treatments was found. This suggests that variations found during the study period could be related to the humidity and temperature fluctuations that occur in the field, thus providing no evidence that the adopted management forms influenced decomposition rate.

The $\mathrm{CO}_{2}$ release method used in this study to evaluate respiratory activity favors the microorganism population, since soil manipulation can eliminate the majority of the microarthropod community. Several authors have, in microcosmos studies, demonstrated the role microarthropods in soil organic matter decomposition process. A low fungivore density (Collembola) has a stimulating effect on microbial respiration, whereas high densities inhibited microorganism respiration Barsdate et al, 1974; Hanlon \& Anderson, 1979).

Mites and insects, belonging to various families, were the two main groups of arthropods found in the soil in 1993 and 1994 (Tables 1 and 2). In general, rates and numbers of individuals from these groups were higher in the organic cropping system, reflecting on Shannon's diversity indices, which were higher in the organic system on all sampling dates (Figure 4), but not on the soil organic matter decomposition (Figure 3 ).

The largest populations of insects were from the Order Collembola, and the number of individuals found in the organic system was three times as high as that in the conventional system, during the first nine months (Table 1). During the following six months, the number of collembolans remained $20 \%$ higher in the organic cropping system than in the conventional (Table 2). These data agree with EI Titi \& Ipach (1989), who verified larger populations of collembolans for the low-input system than for the conventional. Collembolans contribute to the soil's abilitity of suppressing plant pathogens such as Rhizoctonia solani, Fusarium oxysporum f. sp. vasinfectum, and Pythium (Wiggins \& Curl, 1979; Curl et al., 1985a, b; Rickerl et al., 1989; Lartey et al., 1994),
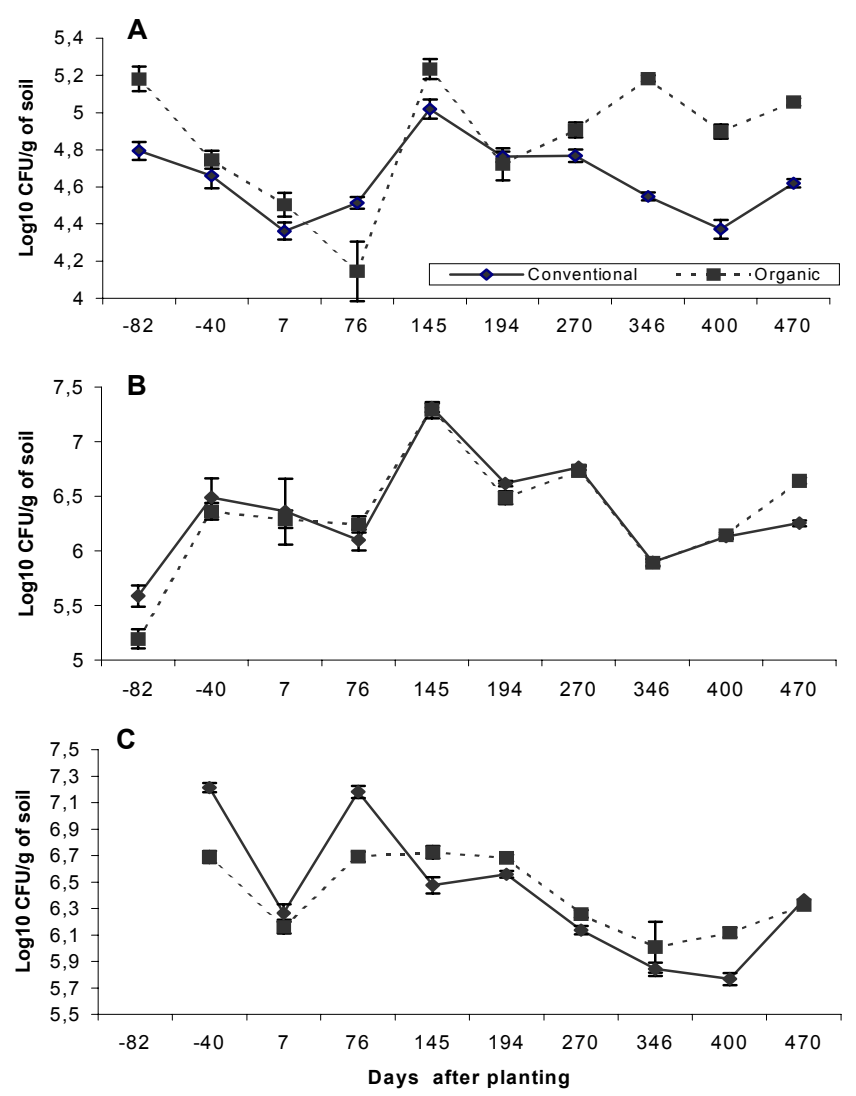

Figure 1 - Dynamic population of fungi, bacteria and actinomycetes in soil from organic (- - ) and conventional (-) cropping systems for tomato and corn. CFU: Colony Forming Units. $A=$ Fungi; $B=$ Actinomycetes; $C=$ Bacteria. The data represent the mean of six replicates. The bars indicate the standart deviation.

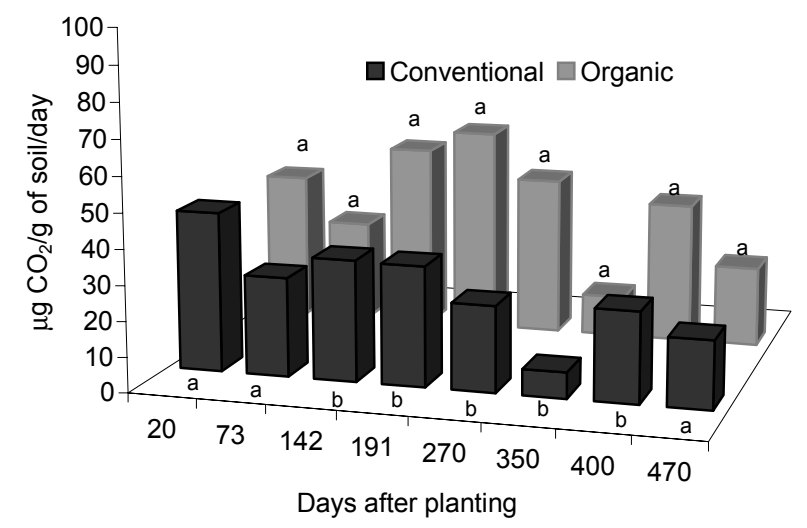

Figure $2-\mathrm{CO}_{2}$ evolution from soil microorganisms of organicand conventional systems for tomato and corn crops. Results were obtained though soil incubation at $25^{\circ} \mathrm{C}$ for 10 days. For each planting time, data followed the same letter did not differ (Duncan 5\%).

because these organisms are, for the most part, mycophagous, modifying the community of fungi. Because in this work the practices in the organic system stimulated the community of collembolans, it can be inferred that these organisms are responsible, at least in part, for the suppression ability in soils enriched with organic matter. Still, in regard to insects, the number of individuals was low for the rest of the orders (Tables 1 and 2). 


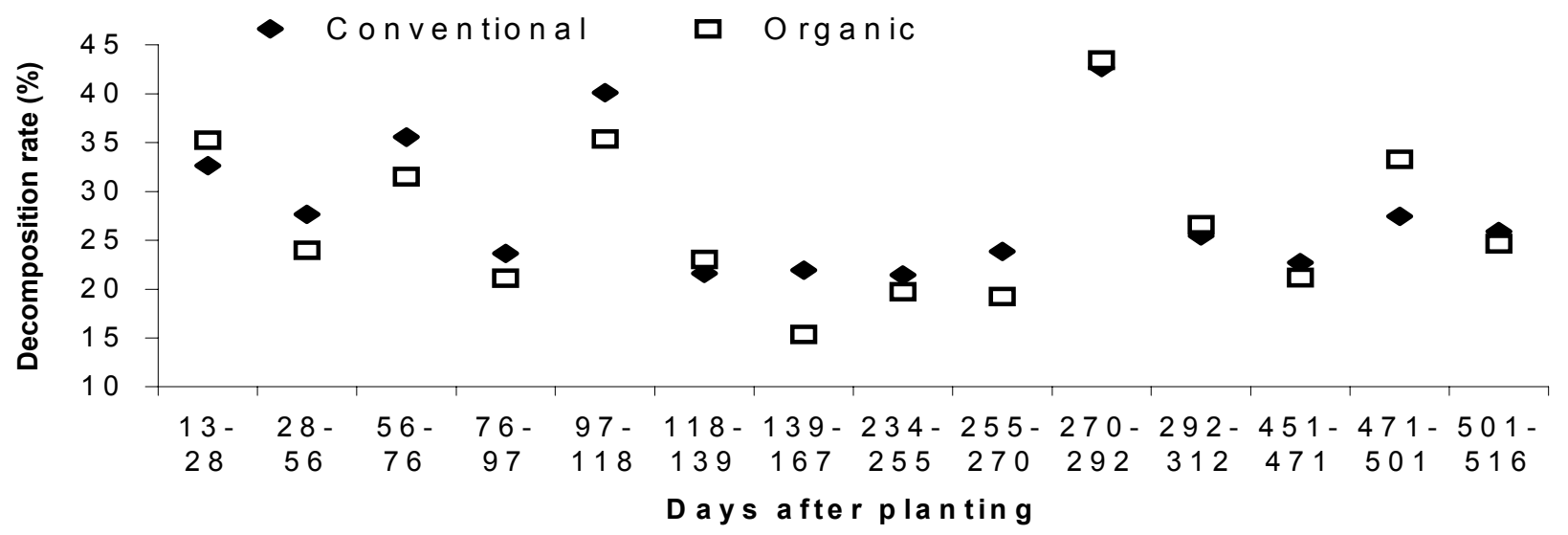

Figure 3 - Organic matter decomposition rate soil of organic and conventional cropping systems.

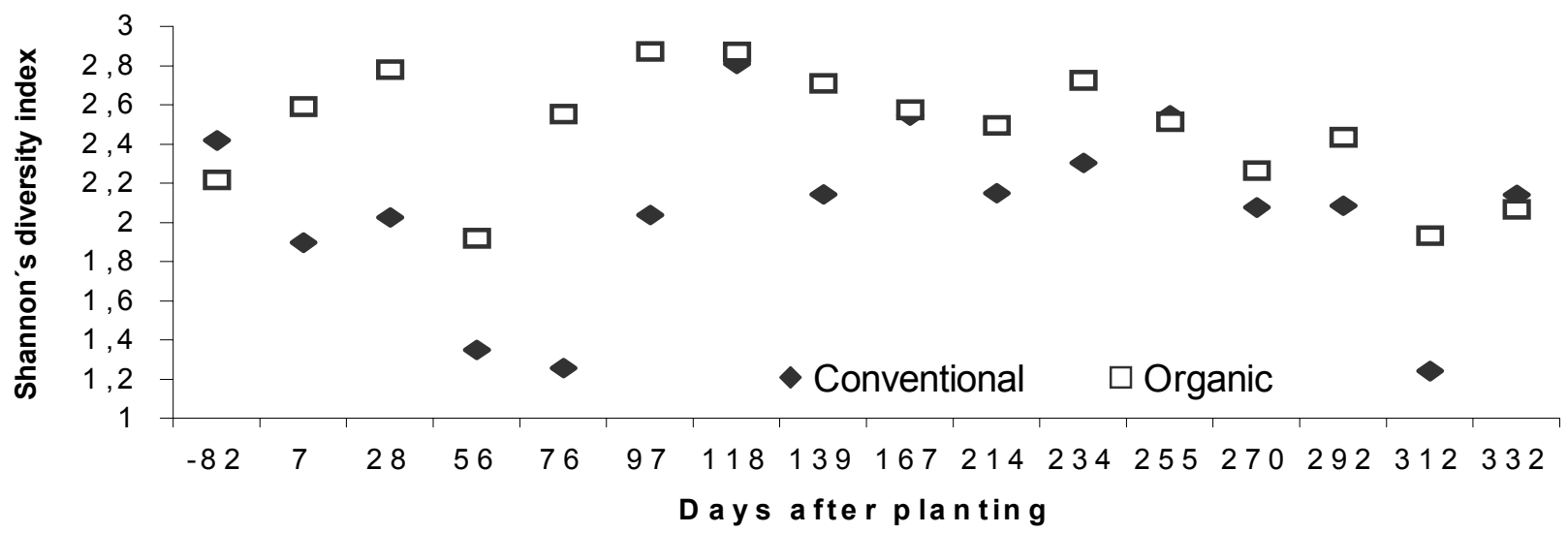

Figure 4 - Shannon's diversity index for soil microarthropods of the organic and conventional cropping systems.

During the first nine months of evaluation (Table 1), for both cropping systems, the largest mite population was of the superfamily Oribatuloidea, followed by the family Galumnidae and by the superfamily Passalozetoidea, all in the suborder Oribatida and with similar behavior between cropping systems. In the suborder Gamasida the most abundant population was Laelapidae and in Actinedida the most abundant was Pygmephoridae, both more numerous in the organic system. Populations in the suborders Acaridida and Ixodida were very small. In the six subsequent months (Table 2), when only the families of mites were quantified, the largest population was of Scheloribatidae followed by Galumnidae, with similar behavior between the systems. The expressive number of individuals in the families Galumnidae and Scheloribatidae for both cropping systems is due to the characteristic these families exhibit toward occupying space in agroecosystems. In the orders Actinedida and Gamasida, families Cunaxidae and Laelapidae were the largest, respectively. In general, mite population densities in the classes Gamasida and Actinedida were higher in the organic system. The fact that the Gamasida showed high numbers is possibly due to a large Collembola population, because these organisms are a source of food for this class of mites. El Titi \& Ipach (1989) verified the existence of larger populations of collembolans and Gamasida mites in the low-input system than in the conventional.

Due to the more abundance of microarthropods in the organic system, it was believed that the organic matter decomposition rate would be higher in this system, because these organisms contribute for organic matter degradation and stimulate microbial activity in the soil (Nosek, 1981). Accordingly, when the presence of Oribatida and Collembola in litterbags incorporated into the organic and the conventional systems was evaluated, a larger number of individuals in the litterbags was found for the organic system (Melo \& Ligo, 1999), indicating that this system contributes for an increase in biological diversity. Since the presence of these organisms in larger numbers was not accompanied by a higher decomposition of organic matter, one can say that the differences in arthropod density found in the soil between the organic and the conventional systems did not reflect on the organic matter decomposition rate, as evaluated by the litterbag method. The community of microarthropods in the soil might have, among other factors, influenced microbial activity, since the organic system showed a higher microbial activity potential than the conventional system. The influence of the soil fauna on the organic matter decomposition rate of forest soils is well documented, but this is not true for agricultural ecosystems (Crossley et al., 
Table 1 - Number of soil microarthropods in the tomato organic (O) and conventional (C) cropping systems.

\begin{tabular}{|c|c|c|c|c|c|c|c|c|c|c|c|c|c|c|c|c|c|c|c|}
\hline \multirow{3}{*}{$\begin{array}{l}\text { Class/Order } \\
\text { I-Arachnida }\end{array}$} & \multirow{3}{*}{$\begin{array}{l}\text { Superfamily/ } \\
\text { Family }\end{array}$} & \multicolumn{18}{|c|}{ Days after the first tomato planting } \\
\hline & & \multicolumn{2}{|c|}{-84} & \multicolumn{2}{|c|}{7} & \multicolumn{2}{|c|}{28} & \multicolumn{2}{|c|}{49} & \multicolumn{2}{|c|}{70} & \multicolumn{2}{|c|}{91} & \multicolumn{2}{|c|}{112} & \multicolumn{2}{|c|}{134} & & \\
\hline & & C & $\mathrm{O}$ & $\mathrm{C}$ & $\mathrm{O}$ & C & $\mathrm{O}$ & $\mathrm{C}$ & $\mathrm{O}$ & $\mathrm{C}$ & $\mathrm{O}$ & C & $\mathrm{O}$ & C & $\mathrm{O}$ & $\mathrm{C}$ & $\mathrm{O}$ & C & $\mathrm{O}$ \\
\hline I.1 Acari & Anoetidae & 0 & 0 & 0 & 0 & 0 & 1 & 0 & 1 & 0 & 0 & 0 & 1 & 0 & 0 & 0 & 0 & 0 & 0 \\
\hline Acaridida & Acaridae & 0 & 0 & 0 & 1 & 0 & 0 & 0 & 1 & 0 & 1 & 0 & 1 & 0 & 5 & 0 & 0 & 0 & 3 \\
\hline Actine dida & Cunaxidae & 1 & 0 & 0 & 2 & 1 & 4 & 2 & 1 & 0 & 1 & 0 & 9 & 1 & 4 & 1 & 18 & 1 & 16 \\
\hline & Eupodidae & 0 & 0 & 0 & 0 & 1 & 25 & 0 & 2 & 0 & 0 & 0 & 1 & 0 & 2 & 0 & 0 & 5 & 3 \\
\hline & Nanorchestidae & 0 & 0 & 4 & 18 & 0 & 19 & 0 & 4 & 1 & 4 & 0 & 6 & 7 & 1 & 1 & 2 & 2 & 1 \\
\hline & Rhagidiidae & 0 & 0 & 0 & 0 & 0 & 0 & 0 & 0 & 0 & 5 & 0 & 1 & 0 & 0 & 0 & 0 & 0 & 3 \\
\hline & Pygmephoridae & 0 & 0 & 1 & 2 & 1 & 37 & 0 & 2 & 0 & 13 & 0 & 30 & 1 & 8 & 0 & 0 & 0 & 1 \\
\hline & Scutacaridae & 0 & 0 & 0 & 0 & 0 & 1 & 0 & 1 & 0 & 0 & 0 & 0 & 0 & 1 & 0 & 0 & 0 & 0 \\
\hline & Tarsonemidae & 0 & 0 & 0 & 0 & 2 & 0 & 0 & 0 & 0 & 0 & 0 & 1 & 2 & 1 & 1 & 5 & 0 & 0 \\
\hline Gamasida & Ascidae & 0 & 0 & 0 & 2 & 0 & 1 & 1 & 4 & 0 & 0 & 0 & 11 & 1 & 7 & 0 & 1 & 1 & 0 \\
\hline & Digamasellidae & 0 & 0 & 0 & 1 & 0 & 0 & 0 & 0 & 0 & 0 & 0 & 0 & 0 & 0 & 0 & 0 & 0 & 0 \\
\hline & Laelapidae & 1 & 6 & 1 & 9 & 1 & 8 & 4 & 7 & 1 & 15 & 3 & 13 & 2 & 27 & 1 & 5 & 4 & 2 \\
\hline & Ma cro chelidae & 1 & 2 & 0 & 1 & 0 & 1 & 0 & 1 & 0 & 1 & 0 & 0 & 0 & 0 & 0 & 0 & 0 & 0 \\
\hline & Ologamasidae & 6 & 8 & 1 & 2 & 0 & 6 & 2 & 3 & 0 & 6 & 0 & 2 & 1 & 5 & 0 & 4 & 1 & 3 \\
\hline & Pachylaelapidae & 12 & 20 & 0 & 2 & 0 & 2 & 0 & 2 & 1 & 0 & 0 & 3 & 0 & 1 & 0 & 0 & 0 & 0 \\
\hline & Parasitidae & 0 & 1 & 0 & 1 & 1 & 1 & 2 & 0 & 0 & 5 & 0 & 2 & 9 & 5 & 2 & 0 & 0 & 0 \\
\hline & Parhoslaspididae & 1 & 0 & 1 & 0 & 0 & 1 & 0 & 0 & 0 & 0 & 0 & 0 & 0 & 0 & 0 & 0 & 0 & 0 \\
\hline & Phytoseiidae & 0 & 0 & 0 & 0 & 0 & 6 & 0 & 0 & 0 & 0 & 1 & 0 & 0 & 1 & 0 & 3 & 1 & 1 \\
\hline & Rhodacaridae & 0 & 0 & 0 & 0 & 0 & 0 & 0 & 0 & 0 & 0 & 0 & 1 & 0 & 0 & 0 & 0 & 0 & 0 \\
\hline & Uropodidae & 1 & 2 & 0 & 6 & 0 & 13 & 1 & 2 & 1 & 7 & 0 & 0 & 0 & 3 & 1 & 15 & 0 & 2 \\
\hline & Immature & 0 & 0 & 0 & 5 & 0 & 5 & 6 & 10 & 0 & 8 & 4 & 20 & 9 & 14 & 0 & 3 & 3 & 8 \\
\hline & Male & 4 & 6 & 0 & 1 & 0 & 1 & 0 & 0 & 0 & 0 & 0 & 1 & 1 & 0 & 0 & 0 & 0 & 0 \\
\hline Ixo dida & Ixodidae & 0 & 1 & 0 & 0 & 0 & 0 & 0 & 0 & 0 & 0 & 0 & 0 & 0 & 0 & 0 & 0 & 0 & 0 \\
\hline Oribatida & Brachichythonidadae & 0 & 1 & 0 & 0 & 0 & 0 & 0 & 0 & 0 & 0 & 0 & 0 & 0 & 0 & 0 & 0 & 0 & 0 \\
\hline & Euphthiracaridae & 0 & 1 & 1 & 3 & 0 & 2 & 0 & 1 & 1 & 0 & 0 & 1 & 0 & 3 & 0 & 1 & 0 & 0 \\
\hline & Galumnidae & 15 & 14 & 20 & 33 & 26 & 22 & 17 & 22 & 10 & 16 & 6 & 10 & 12 & 19 & 3 & 14 & 6 & 9 \\
\hline & Haplochtho ni idae & 0 & 0 & 0 & 0 & 0 & 1 & 0 & 1 & 0 & 0 & 0 & 0 & 0 & 0 & 0 & 0 & 0 & 0 \\
\hline & Microzetidae & 0 & 0 & 0 & 0 & 0 & 0 & 2 & 0 & 0 & 1 & 0 & 1 & 0 & 2 & 1 & 1 & 0 & 0 \\
\hline & Oppiidae & 0 & 0 & 2 & 4 & 2 & 11 & 3 & 13 & 2 & 4 & 3 & 5 & 16 & 3 & 0 & 0 & 1 & 0 \\
\hline & Oribatuloidea & 21 & 66 & 46 & 46 & 23 & 47 & 106 & 78 & 38 & 26 & 33 & 26 & 18 & 31 & 40 & 28 & 56 & 17 \\
\hline & Oribatellidae & 0 & 3 & 1 & 1 & 0 & 1 & 0 & 1 & 0 & 0 & 0 & 1 & 3 & 0 & 0 & 0 & 1 & 2 \\
\hline & Passalozetoidea & 6 & 13 & 1 & 4 & 3 & 6 & 3 & 1 & 1 & 4 & 7 & 8 & 37 & 24 & 6 & 4 & 16 & 0 \\
\hline & Suctobelbidae & 0 & 0 & 0 & 0 & 0 & 2 & 3 & 1 & 0 & 0 & 1 & 1 & 7 & 0 & 1 & 1 & 2 & 0 \\
\hline & Scheloribatidae & 21 & 59 & 48 & 46 & 23 & 47 & 106 & 78 & 36 & 26 & 33 & 26 & 17 & 31 & 45 & 28 & 56 & 17 \\
\hline & Thrypo chtho niidae & 0 & 0 & 0 & 0 & 0 & 0 & 0 & 0 & 0 & 0 & 0 & 16 & 3 & 14 & 0 & 0 & 2 & 1 \\
\hline & Immature & 0 & 0 & 0 & 1 & 0 & 2 & 1 & 0 & 1 & 0 & 0 & 0 & 0 & 1 & 0 & 0 & 0 & 0 \\
\hline & Oribatida & 2 & 3 & 1 & 1 & 0 & 2 & 3 & 2 & 1 & 2 & 1 & 3 & 0 & 0 & 2 & 7 & 1 & 0 \\
\hline II. Insecta & & & & & & & & & & & & & & & & & & & \\
\hline Coleoptera & Carabidae & 0 & 0 & 0 & 0 & 1 & 0 & 0 & 1 & 0 & 1 & 0 & 1 & 1 & 0 & 2 & 2 & 0 & 0 \\
\hline & Cicindelidae & 0 & 0 & 1 & 0 & 0 & 0 & 0 & 0 & 0 & 0 & 0 & 1 & 0 & 0 & 0 & 0 & 0 & 0 \\
\hline & Hydroscaphidae & 0 & 0 & 0 & 1 & 0 & 1 & 0 & 0 & 0 & 0 & 0 & 0 & 0 & 0 & 0 & 0 & 0 & 0 \\
\hline & Nitidulidae & 0 & 0 & 1 & 0 & 0 & 0 & 0 & 0 & 0 & 0 & 0 & 0 & 1 & 1 & 1 & 0 & 0 & 0 \\
\hline & Scarabaedidae & 0 & 0 & 0 & 0 & 0 & 1 & 0 & 0 & 0 & 0 & 0 & 0 & 0 & 0 & 2 & 0 & 0 & 0 \\
\hline & Scolytidae & 0 & 0 & 0 & 0 & 0 & 0 & 0 & 0 & 0 & 0 & 0 & 1 & 1 & 0 & 0 & 0 & 0 & 0 \\
\hline & Staphylinidae & 0 & 0 & 0 & 0 & 2 & 1 & 0 & 0 & 0 & 0 & 0 & 3 & 5 & 5 & 0 & 1 & 2 & 4 \\
\hline & Larva & 4 & 1 & 5 & 0 & 0 & 6 & 0 & 1 & 0 & 1 & 0 & 10 & 4 & 11 & 0 & 17 & 7 & 4 \\
\hline Collembola & Entomobryidae & 7 & 10 & 0 & 2 & 2 & 43 & 0 & 0 & 0 & 0 & 1 & 19 & 36 & 30 & 26 & 35 & 32 & 52 \\
\hline & Isotomidae & 4 & 1 & 5 & 71 & 3 & 93 & 0 & 0 & 0 & 0 & 2 & 38 & 16 & 60 & 5 & 2 & 12 & 32 \\
\hline & Poduridae & 0 & 1 & 1 & 39 & 0 & 34 & 0 & 0 & 0 & 0 & 0 & 5 & 23 & 44 & 2 & 15 & 33 & 13 \\
\hline Diptera & Adult & 0 & 0 & 5 & 5 & 10 & 11 & 0 & 0 & 0 & 0 & 9 & 19 & 9 & 12 & 5 & 8 & 21 & 20 \\
\hline & Larva & 1 & 0 & 0 & 0 & 1 & 5 & 0 & 1 & 0 & 1 & 0 & 0 & 1 & 0 & 0 & 1 & 2 & 1 \\
\hline Homoptera & & 0 & 0 & 0 & 1 & 0 & 0 & 0 & 0 & 0 & 0 & 1 & 0 & 0 & 2 & 2 & 1 & 3 & 3 \\
\hline Hymenoptera & Formicidae & 0 & 0 & 0 & 0 & 0 & 4 & 0 & 0 & 0 & 0 & 0 & 3 & 3 & 9 & 0 & 3 & 5 & 5 \\
\hline Psocoptera & & 1 & 1 & 1 & 0 & 1 & 0 & 0 & 0 & 0 & 0 & 2 & 1 & 2 & 0 & 1 & 2 & 0 & 1 \\
\hline
\end{tabular}

Data expressed in number of individuals per $785 \mathrm{~mL}$ soil and represent the mean of six replicates. 
Table 2 - Number of soil microarthropods in the corn organic (O) and conventional (C) cropping systems.

\begin{tabular}{|c|c|c|c|c|c|c|c|c|c|c|c|c|c|c|c|}
\hline \multirow{3}{*}{$\frac{\text { Class/order }}{\text { I-Arachnida }}$} & \multirow{3}{*}{ Family } & \multicolumn{14}{|c|}{ Days after the first tomato planting } \\
\hline & & \multicolumn{2}{|c|}{197} & \multicolumn{2}{|c|}{218} & \multicolumn{2}{|c|}{240} & \multicolumn{2}{|c|}{262} & \multicolumn{2}{|c|}{284} & \multicolumn{2}{|c|}{304} & \multicolumn{2}{|c|}{325} \\
\hline & & C & 0 & C & 0 & C & 0 & C & 0 & C & 0 & C & 0 & C & 0 \\
\hline I.1 Acari & Anoetidae & 0 & 0 & 1 & 0 & 0 & 0 & 1 & 0 & 0 & 0 & 0 & 0 & 0 & 0 \\
\hline Acaridida & Acaridae & 0 & 0 & 0 & 0 & 1 & 0 & 0 & 0 & 0 & 0 & 0 & 0 & 0 & 0 \\
\hline \multirow[t]{7}{*}{ Actinedida } & Cunaxidae & 4 & 9 & 8 & 7 & 17 & 17 & 16 & 14 & 7 & 17 & 7 & 18 & 6 & 8 \\
\hline & Erythraeidae & 0 & 0 & 1 & 1 & 2 & 0 & 0 & 0 & 0 & 1 & 0 & 0 & 0 & 0 \\
\hline & Eupodidae & 0 & 2 & 0 & 0 & 0 & 11 & 1 & 11 & 3 & 4 & 1 & 4 & 9 & 10 \\
\hline & Nanorchestidae & 0 & 2 & 0 & 5 & 5 & 10 & 1 & 3 & 1 & 3 & 1 & 2 & 2 & 2 \\
\hline & Rhagidiidae & 0 & 1 & 0 & 0 & 2 & 2 & 0 & 0 & 0 & 0 & 1 & 2 & 1 & 0 \\
\hline & Pygmephoridae & 2 & 0 & 0 & 2 & 1 & 2 & 3 & 1 & 7 & 3 & 0 & 4 & 0 & 0 \\
\hline & Tarsonemidae & 0 & 0 & 0 & 0 & 2 & 10 & 0 & 4 & 0 & 1 & 0 & 0 & 1 & 0 \\
\hline \multirow[t]{14}{*}{ Gamasida } & Ascidae & 0 & 1 & 1 & 0 & 4 & 5 & 5 & 11 & 4 & 4 & 5 & 12 & 1 & 2 \\
\hline & Amoroseiidae & 0 & 0 & 0 & 1 & 0 & 0 & 0 & 0 & 0 & 0 & 0 & 0 & 0 & 0 \\
\hline & Digamasellidae & 0 & 0 & 0 & 0 & 0 & 0 & 0 & 1 & 0 & 0 & 0 & 0 & 0 & 0 \\
\hline & Laelapidae & 3 & 1 & 2 & 13 & 17 & 48 & 44 & 41 & 5 & 20 & 1 & 18 & 7 & 12 \\
\hline & Macrochelidae & 0 & 0 & 0 & 0 & 0 & 0 & 0 & 0 & 0 & 1 & 0 & 1 & 1 & 2 \\
\hline & Ologamasidae & 1 & 4 & 1 & 1 & 2 & 5 & 9 & 12 & 6 & 5 & 5 & 4 & 4 & 7 \\
\hline & Pachylaelapidae & 0 & 2 & 0 & 0 & 0 & 1 & 1 & 1 & 0 & 0 & 0 & 0 & 0 & 0 \\
\hline & Parasitidae & 0 & 0 & 1 & 17 & 4 & 10 & 1 & 7 & 2 & 0 & 4 & 7 & 0 & 4 \\
\hline & Parhoslaspididae & 0 & 1 & 0 & 0 & 3 & 0 & 0 & 0 & 0 & 0 & 0 & 1 & 0 & 0 \\
\hline & Phytoseiidae & 0 & 0 & 0 & 0 & 1 & 0 & 4 & 1 & 0 & 5 & 4 & 4 & 2 & 0 \\
\hline & Rhodacaridae & 0 & 0 & 0 & 0 & 0 & 0 & 0 & 4 & 0 & 1 & 0 & 7 & 0 & 1 \\
\hline & Uropodidae & 0 & 15 & 0 & 37 & 2 & 24 & 1 & 8 & 1 & 27 & 0 & 17 & 0 & 1 \\
\hline & Immature & 0 & 2 & 1 & 21 & 16 & 19 & 24 & 7 & 4 & 9 & 5 & 7 & 3 & 1 \\
\hline & Male & 1 & 4 & 0 & 5 & 6 & 2 & 4 & 3 & 0 & 0 & 0 & 1 & 0 & 0 \\
\hline \multirow[t]{13}{*}{ Oribatida } & Brachichythonidadae & 0 & 0 & 0 & 0 & 0 & 0 & 0 & 0 & 0 & 0 & 0 & 0 & 1 & 0 \\
\hline & Euphthiracaridae & 0 & 0 & 0 & 0 & 5 & 1 & 1 & 2 & 0 & 3 & 5 & 4 & 3 & 5 \\
\hline & Galumnidae & 123 & 11 & 19 & 94 & 45 & 51 & 60 & 56 & 31 & 64 & 20 & 108 & 18 & 106 \\
\hline & Haplochthoniidae & 1 & 0 & 0 & 0 & 0 & 0 & 0 & 0 & 0 & 00 & 0 & 0 & 0 & 0 \\
\hline & Microzetidae & 0 & 0 & 0 & 1 & 1 & 0 & 1 & 5 & 0 & 0 & 0 & 0 & 0 & 0 \\
\hline & Oppiidae & 0 & 0 & 0 & 0 & 7 & 2 & 0 & 5 & 1 & 1 & 1 & 0 & 0 & 0 \\
\hline & Oribatellidae & 1 & 1 & 3 & 4 & 8 & 3 & 15 & 6 & 5 & 7 & 1 & 10 & 6 & 1 \\
\hline & Phthriracaridae & 0 & 0 & 0 & 0 & 1 & 0 & 0 & 0 & 0 & 0 & 0 & 1 & 2 & 0 \\
\hline & Suctobelbidae & 0 & 0 & 2 & 0 & 0 & 0 & 0 & 0 & 0 & 0 & 0 & 0 & 0 & 0 \\
\hline & Scheloribatidae & 53 & 48 & 144 & 132 & 210 & 163 & 365 & 272 & 175 & 140 & 90 & 122 & 68 & 88 \\
\hline & Thrypo chtho niidae & 0 & 0 & 1 & 0 & 0 & 0 & 0 & 0 & 0 & 0 & 0 & 0 & 0 & 0 \\
\hline & Immature & 20 & 17 & 35 & 33 & 139 & 82 & 99 & 125 & 54 & 29 & 10 & 26 & 5 & 11 \\
\hline & Oribatida & 0 & 4 & 3 & 4 & 15 & 4 & 1 & 2 & 1 & 0 & 0 & 4 & 2 & 4 \\
\hline \multicolumn{16}{|l|}{ II. Inse cta } \\
\hline Coleoptera & Carabidae & 1 & 2 & 2 & 0 & 3 & 5 & 1 & 1 & 2 & 1 & 0 & 7 & 1 & 6 \\
\hline & Cicindelidae & 0 & 1 & 3 & 2 & 0 & 0 & 0 & 0 & 0 & 0 & 0 & 0 & 0 & 0 \\
\hline & Nitidulidae & 0 & 0 & 1 & 1 & 0 & 0 & 0 & 0 & 0 & 0 & 0 & 0 & 0 & 1 \\
\hline & Scarabaedidae & 1 & 3 & 0 & 2 & 0 & 0 & 0 & 0 & 0 & 0 & 1 & 0 & 0 & 0 \\
\hline & Scolytidae & 0 & 2 & 2 & 0 & 1 & 0 & 0 & 0 & 0 & 1 & 1 & 0 & 0 & 0 \\
\hline & Staphylinidae & 1 & 2 & 1 & 4 & 7 & 6 & 1 & 0 & 0 & 0 & 0 & 0 & 0 & 0 \\
\hline & Larva & 1 & 10 & 8 & 8 & 20 & 28 & 5 & 16 & 3 & 6 & 3 & 2 & 1 & 1 \\
\hline Collemb ola & Entomobryidae & 0 & 8 & 10 & 30 & 21 & 41 & 15 & 13 & 2 & 23 & 1 & 0 & 0 & 1 \\
\hline & Isotomidae & 15 & 104 & 29 & 41 & 81 & 266 & 223 & 326 & 125 & 137 & 516 & 451 & 69 & 92 \\
\hline & Poduridae & 0 & 8 & 29 & 35 & 24 & 33 & 234 & 128 & 54 & 30 & 33 & 33 & 104 & 174 \\
\hline Diptera & Adult & 31 & 68 & 20 & 24 & 7 & 6 & 5 & 16 & 7 & 2 & 4 & 8 & 7 & 1 \\
\hline & Larva & 0 & 0 & 0 & 2 & 1 & 9 & 1 & 3 & 0 & 2 & 1 & 2 & 2 & 3 \\
\hline Hymenop tera & Formicidae & 4 & 8 & 6 & 20 & 16 & 5 & 17 & 26 & 13 & 4 & 0 & 3 & 2 & 12 \\
\hline & Wasp & 1 & 0 & 1 & 3 & 3 & 1 & 1 & 1 & 0 & 3 & 0 & 0 & 0 & 0 \\
\hline Psocoptera & & 15 & 12 & 7 & 22 & 0 & 0 & 0 & 0 & 1 & 2 & 1 & 0 & 0 & 1 \\
\hline
\end{tabular}

Data expressed in number of individuals per $785 \mathrm{~mL}$ soil and represent the mean of six replicates. 
1989). In agroecosystems the effect of the fauna on the organic matter decomposition rate seems not to be very significant and consequently, there are many points that need to be clarified when it comes to the role of fauna in agricultural soils. Occasionally, and similarly among the crop systems evaluated, individuals belonging in the groups Aranae, Chilopoda, Diploploda, Diplura, Pauropoda, Protura and Symphila were collected. In addition to these, individuals of the insect orders Dermaptera, Hemiptera, Homoptera, Isoptera and Thysanoptera were found in limited numbers.

The higher biological diversity in the organic system is important because it contributes to keeping the biological equilibrium, essential in an agroecosystem. This equilibrium may bring about greater stability for the system and consequently fewer problems with diseases and pests.

With respect to the worm community, after a oneyear period of cropping, the soil in the organic system showed at least a ten-fold higher number of specimens per $3140 \mathrm{~mL}$ soil sample than the conventional system. After 370,407 and 471 days from planting a total of 18, 24 and 101 specimens were found in the organic cropping system, and 1, 2 and 12 specimens were found in the conventional system, respectively. These data agree with Bokhorst (1989), who found that the number of worm individuals per square meter, in a soil planted with sugar beets, was five times higher in the organic system as compared to the conventional. Also, El Titi \& Ipach (1989) observed the existence of greater worm biomass in a low-input system than in the conventional. The higher number of species in the organic system is possibly due to the availability of organic substrates for them to breed on and the absence of pesticides. On the other hand, the presence of pesticides explains the small number of species in the conventional system, since the worms are sensitive to the products used in the conventional system (Lee, 1985). These organisms are important because they not only improve the physical properties (Lee, 1985), but also contribute to the soil's ability to suppress pathogens, such as $R$. solani, among others (Stephens et al., 1993). No worm specimens were found in the recently plowed soil (81 days before planting) and in the evaluations carried out at planting time and 90 days after planting the seeding, as well as in the organic compost.

\section{REFERENCES}

ABREU JR., H. Práticas alternativas de controle de pragas e doenças na agricultura. Campinas: EMOPI, 1998. 112p.

BETTIOL, W.; TRATCH, R.; GALVÃO, J.A.H. Controle de doenças de plantas com biofertilizantes. Jaguariúna: EMBRAPA, CNPMA, 1997. 22p. (Circular Técnica, 2).

BARSDATE, R.J.; PRETKI, R.T.; FENCHEL, T. Phosphorus cycle of model ecosystems: significance for decomposer food chains and effect of bacterial grazers. OIKOS, v.25, p.239-251, 1974.

BOKHORST, J.G. The organic farm at Nageli. In: ZADOKS, J.C. Development of farming systems. Pudoc: Wageningen, 1989. p.57-65.

BRUSSAARD, L.; VAN VEEN, J.A.; KOOISTRA, M.J.; LEBBINK, E. The Dutch programme on soil ecology of arable farming systems: I. Objectives, approach and some preliminary results. Ecological Bulletins, v.39, p.3540, 1988.
BRUSSAARD, L.; BOUWMAN, L.A.; GEURS, M.; HASSINK, J.; ZWART, K.B. Biomass, composition and temporal dynamics of soil organisms of a silt loam soil under conventional and integrated management. Netherlands Journal of Agricultural Science, v.38, p.283-302, 1990.

CASTRO, O.M. de; PRADO, H. do; SEVERO, A.C.R.; CARDOSO, E.J.B.N. Avaliação da atividade de microrganismos do solo em diferentes sistemas de manejo de soja. Scientia Agricola, v.50, p.212-219, 1993.

CATTELAN, A.J.; VIDOR, C. Sistemas de culturas e a população microbiana do solo. Revista Brasileira de Ciência do Solo, v.14, p.125-132, 1990.

CROSSLEY JR., D.A.; COLEMAN, D.C.; HENDRIX, P.F. The importance of the fauna in agricultural soils: research approaches and perspectives. Agriculture, Ecosystems and Environment, v.27, p.47-55, 1989.

CURL, E.A.; HARPER, J.D.; PETERSON, C.M.; GUDAUSKAS, R.T. Relationships of mycophagous collembola and Rhizoctonia solani populations in biocontrol. Phytopathology, v.75, p.1360 (Abstract). 1985a.

CURL, E.A.; GUDAUSKAS, R.T.; HARPER, J.D.; PETERSON, C.M. Effects of soil insects on populatons and germination of fungal propagules. In: PARKER, C.A.; ROVIRA, A.D.; MOORE, K.J.; WONG, P.T.W. Ecology and management of soilborne plant pathogens. St. Paul: APS, 1985b. p.20-23.

EL TITI, A.; IPACH, U. Soil fauna in sustainable agriculture: results of na integrated farming system at Lautenbach, F.R.G. Agriculture, Ecosystems and Environment, v.27, p.561-572, 1989.

GLIESSMAN, S.R.; SWEZEY, S.L.; ALLISON, J.; COCHRAN, J.; FARRELL, J.; KLUSON, R.; ROSADO-MAY, F.; WERNER, M. Strawberry production systems during conversion to organic management. California Agriculture, v.44, p.4-7, 1990.

GLIESSMAN, S.R.; WERNER, M.R.; SWEZEY, S.L.; CASWELL, E.; COCHRAN, J.; ROSADO-MAY, F. Conversion to organic strawberry management changes ecological processes. California Agriculture, v.50, p.24-31, 1996.

GRIGOROVA, R.; NORRIS, J.R. Methods in microbiology. Techniques in microbial ecology. London: Academic Press, 1990, 627p.

GRISI, B.M. Método químico de medição da respiração edáfica: alguns aspectos técnicos. Ciência e Cultura, v.30, p.82-88, 1978.

HANLON, R.D.G.; ANDERSON, J.M. The effects of Collembola grazing on microbial activity in decomposing leaf litter. Oecologia, v.30, p.93-99, 1979.

LADD, J.N.; AMATO, M.; LI-KAI, Z.; ZCHULTZ, J.E. Differential effects of rotation, plant residue and nitrogen fertilizers on microbial biomass and organic matter in na Australian Alfisol. Soil Biology \& Biochemistry, v.26, p.821-831, 1994.

LAMBAIS, M.R. Atividades microbiológicas envolvidas na mineralização da matéria orgânica: potenciais indicadores da qualidade de solos agrícolas. In: MARTOS, H.L.; MAIA, N.B. Indicadores ambientais. Sorocaba: PUC, 1997. p.167-174.

LARTEY, R.T.; CURL, E.A.; PETERSON, C.M. Interacitons of mycophagous collembola and biological control fungi in the suppression of Rhizoctonia solani. Soil Biology \& Biochemistry, v.26, p.81-88, 1994.

LEE, K.E. Earthworms: Their ecology and relationships with soils and land use. Sydney: Academic Press, 1985. 411p.

MELO, L.A.S.; LIGO, M.A.V. Amostragem de solo e uso de "litterbags" na avaliação populacional de microartrópodos edáficos. Scientia Agricola, v.56, p.523-528, 1999

NOSEK, J. Ecological niche of Collembola in biogeocoenoses. Pedobiologia, v.21, p.166-171, 1981

PASCHOAL, A.B. Modelos sustentáveis de agricultura. Agricultura Sustentável, v.2, p.11-16, 1995

RICKERL, D.H.; CURL, E.A.; TOUCHTON, J.T. Tillage and rotation effects on Collembola populations and Rhizoctonia infestation. Soil \& Tillage Research, v.15, p.41-49, 1989.

RODRIGUES, G.S.; LIGO, M.A.V.; MINEIRO, J.L.de C. Organic matter decomposition and microartropod community structure in corn fields under low input and intensive management in Guaíra, SP. Scientia Agricola, v.54, p.69-77, 1997.

SANTOS, P.F.; WHITFORD, W.G. The effects of microarthopods on litter decompositions in a Chihuahuan desert ecosystem. Ecology, v.62, p.654$663,1981$.

SHANNON, C.E.; WEAVER, W. The mathematical theory of communications. Urbana: The University of Illinois Press, 1949. 117p.

STEPHENS, P.M.; DAVOREN, C.W.; DOUBE, B.M.; RYDER, M.H.; BENGER, A.M.; NEATE, S.M. Reduced severety of Rhizoctonia solani disease on wheat seedlings associated with the presence of the earthworm Aporrectodea trapezoides (LUMBRICIDAE). Soil Biology \& Biochemistry, v.25, p.1447-1484, 1993.

SWEZEY, S.L.; RIDER, J.; WERNER, M.R.; BUCHANAN, M.; ALLISON, J.; GLIESSMAN, S.R. Granny Smith conversions to organic show early success. California Agriculture, v.48, p.36-44, 1994.

TUITE, J. Plant pathological methods fungi and bacteria. Minneapolis: Burgess, 1969. 239p.

WIGGINS, E.A.; CURL, E.A. Interactions of Collembola and microflora of cotton rhizosphere. Phytopathology, v.69, p.244-249, 1979.

Received July 29, 2001 